RIBEIRO, WS; CARNEIRO, CS; FRANÇA, CFM; PINTO, CMF; LIMA, PCC; FINGER, FL. 2018. 1-MCP efficiency in quality of ornamental peppers. Horticultura Brasileira 36: 510-514. DOI - http://dx.doi.org/10.1590/S0102-053620180414

\title{
1-MCP efficiency in quality of ornamental peppers
}

\author{
Wellington S Ribeiro'; Clebson dos S Carneiro²; Christiane de Fátima M França ${ }^{3}$; Cleide Maria F Pinto ${ }^{4}$; \\ Paula Cristina C Lima²; Fernando L Finger ${ }^{2}$
}

${ }^{1}$ Universidade Estadual da Paraíba (UFPB), Lagoa Seca-PB, Brazil; wellingtisouto@yahoo.com.br ; ${ }^{2}$ Universidade Federal de Viçosa (UFV), Viçosa-MG, Brazil; clebson.carneiro@ufv.br; paulinhahlima@yahoo.com.br; ffinger@ufv.br; ${ }^{3}$ Universidade Federal do Oeste da Bahia (UFOB), Barra-BA, Brazil; christiane.franca@ufob.edu.br; ${ }^{4}$ Empresa de Pesquisa Agropecuária de Minas Gerais (EPAMIG), Viçosa-MG, Brazil; cleidemariaferreirapinto@yahoo.com.br

\begin{abstract}
1-MCP has been effectively used as an antagonist of ethylene deleterious actions in flowers and ornamental plants. The objective was to evaluate the efficiency of $1-\mathrm{MCP}\left(0.0,0.5,1.0\right.$ and $\left.1.5 \mathrm{~g} \mathrm{~m}^{-3}\right)$ in maintaining post-production quality of exogenous ethylene sensitive ornamental pepper. Two commercial varieties were evaluated: Pimenta Colorida and Pimentão Ornamental, both Capsicum annuum. The pre-treatment with 1-MCP, regardless of the applied concentration, was effective in blocking the ethylene action reducing the leaves abscission, flowers and fruits of both genotypes by $100 \%$. Plants pretreated with 1-MCP had postproduction life increased by eight and nine days for Pimenta Colorida and Pimentão Ornamental, respectively. The 1-MCP application at the concentration of $1.0 \mathrm{~g} \mathrm{~m}^{-3}$ is efficient in maintaining ornamental quality and prolonging the shelf life of Pimenta Colorida and Pimentão Ornamental.
\end{abstract}

Keywords: Capsicum annuum, ornamental plants, sensitivity, transport.

\section{RESUMO}

\section{Eficiência do 1-MCP na qualidade de pimenteiras ornamentais}

O 1-MCP tem sido efetivamente utilizado como antagonista das ações deletérias do etileno em flores e plantas ornamentais. O objetivo foi avaliar a eficiência do $1-\operatorname{MCP}\left(0,0 ; 0,5 ; 1,0\right.$ e $\left.1,5 \mathrm{~g} \mathrm{~m}^{-3}\right)$ na manutenção da qualidade pós-produção de pimenteiras ornamentais sensíveis ao etileno exógeno. Foram avaliadas duas variedades comerciais: Pimentão Ornamental e Pimenta Colorida, ambas Capsicum annuum. O pré-tratamento com 1-MCP, independente da concentração aplicada, foi eficaz em bloquear a ação do etileno reduzindo em $100 \%$ a abscisão de folhas, flores e frutos de ambos os genótipos. As plantas pré-tratadas com 1-MCP tiveram a vida de pós-produção aumentada em oito e nove dias para Pimenta Colorida e Pimentão Ornamental, respectivamente. A aplicação de 1-MCP na concentração de $1,0 \mathrm{~g} \mathrm{~m}^{-3}$ é eficiente em manter a qualidade ornamental e prolongar a vida de prateleira da Pimenta Colorida e Pimentão Ornamental.

Palavras chave: Capsicum annuum, plantas ornamentais, sensibilidade, transporte.

\section{Received on March 14, 2017; accepted on September 14, 2018}

$\mathrm{S}$ pecies of the genus Capsicum have different ethylene sensitivity levels. In potted peppers, ethylene triggers a series of deleterious responses, among them, the abscission of fruits and leaves as a reaction to tissue sensitivity. However, other negative effects are visible, such as the acceleration of chlorophyll degradation and the senescence process (Beaudry \& Kays, 1998; Krajayklang et al., 2000; Brackmann et al., 2004; Segatto et al., 2013).

The need for chemical protection against the ethylene action has been recommended for many ornamental potted plants, in which low ethylene concentrations cause rapid losses in ornamental quality (Serek et al., 1994). In this sense, cyclopropenes have been effectively used to prevent the deleterious ethylene effects on plants (Sisler \& Serek, 1999).

The effects of these compounds as ethylene antagonists are attributed to their molecular structure which allows very strong binding to the low valence electron donor compounds present at the receptor. They compete with ethylene for their binding sites and remain bound to these receptors for a long time, thus avoiding the ethylene-dependent responses (Sisler \& Serek, 1997, 1999).

$1-\mathrm{MCP}$ is one of the most useful compounds among cyclopropenes for this purpose. It is non-toxic, stable at room temperature, active at relatively low concentrations, providing protection for a long period of up to 12 days after a single exposure, without any detectable odor (Finger \& Barbosa, 2006). However, depending on the shelf-life of these plants, the sensitivity of the plant tissue can be resumed by the synthesis of new binding sites allowing the ethylene action resumption (Blankenship \& Dole, 2003).

So, one of the most sought goals in the post-production stage of ornamental plants, including pepper plants, is the nullification or delay of the deleterious effects caused by ethylene with minimal application of antagonists. The Epidendrum ibaguense orchid treated with 1-MCP had shelf life doubled when compared to control flowers (Finger et al., 2008). Similar results were obtained in cultivars of Phalaenopsis, where the 
1-MCP application inhibited the floral buds and flowers abscission, effectively blocking the ethylene action (Sun et al., 2009).

Fumigation with cyclolefins 1-DCP and 1-OCP have been shown to be efficient in reducing the flower abscission rate in potted mini-roses even when ethylene is not the primary agent in inducing plant senescence (Buanong et al., 2005).

The 1-MCP effectiveness in delaying the senescence symptoms on majority of ornamental plants is dependent on application temperature, concentration and stage of plants development (Finger \& Barbosa, 2006).

The objective of the present research was to evaluate the 1-MCP action on the longevity of two ornamental pepper cultivars, sensible to ethylene.

\section{MATERIAL AND METHODS}

\section{Localization, obtainment and maintenance of seedlings}

Pepper seedlings were produced in protected environment in polystyrene trays filled with commercial Bioplant ${ }^{\mathbb{B}}$ substrate. After reaching two to three pairs of leaves, seedlings were transplanted into $900 \mathrm{~mL}$ vessels (11 $\mathrm{cm}$ high, $9.5 \mathrm{~cm}$ basal diameter, $13.5 \mathrm{~cm}$ upper diameter). Bioplant ${ }^{\mathbb{B}}$ commercial substrate was used to fill the vessels.

At planting, the substrate was fertilized with $2.5 \mathrm{~g}$ of NPK $0-10-10$ formulation. During the experiment, fertilization was done every 20 days with $10 \mathrm{~g}$ of NPK formulation 10-0-10.

Plants were watered, from sowing to transplanting, once a day with enough water to moisten the substrate until field capacity. From transplanting until establishment of the seedlings, the substrate was watered with 150 $\mathrm{mL}$ of water/pot daily. From the initial establishment period of the seedlings until the last day of the experiment, the substrates were watered with $150 \mathrm{~mL}$ of water/pot daily. During watering, the water was deposited directly on the substrate, with occasional wetting of the leaves.

\section{1-MCP application}

The commercial cultivars Pimenta Colorida and Pimentão Ornamental (Capsicum annuum) were used in this experiment. Plants were taken to the laboratory at the commercialization point, characterized by $50 \%$ of the population with at least $30 \%$ fully ripened fruits, visually determined (fruits with the maximum growth size and typical size of each species, with the specific color demanded by the market and not wilted). The treatments were carried out in a $60 \mathrm{~L}$ hermetic chamber, where the plants remained in the dark and without irrigation during the treatment, simulating the transport condition. In this environment, the commercial product EthylBloc ${ }^{\circledR}(0.14 \%$ i.a., Rohm and Hass Química Ltda., São Paulo, Brazil) was dissolved in water at $50^{\circ} \mathrm{C}$, releasing $1-\mathrm{MCP}$ gas. The treatments were composed of: 1) External control, in which the plants were kept in bench condition with average temperature of $20^{\circ} \mathrm{C}$ and $8-10$ ( $\mu \mathrm{mol} \mathrm{s}{ }^{-1} \mathrm{~m}^{-1}$ of fluorescent light; 2) Internal control, in which the plants were kept inside the chambers without the ethylene application or 1-MCP; 3) Ethylene at $10 \mu \mathrm{L}^{-1}$; 4) $0.5 \mathrm{~g} \mathrm{~m}^{-3}$ of 1-MCP; 5) $1.0 \mathrm{~g} \mathrm{~m}^{-3}$ of 1-MCP; 6) 1.5 $\mathrm{g} \mathrm{m}^{-3}$ of 1 -MCP; 7) $0.5 \mathrm{~g} \mathrm{~m}^{-3}$ of $1-\mathrm{MCP}$ $+10 \mu \mathrm{L}^{-1}$ of ethylene; 8) $1.0 \mathrm{~g} \mathrm{~m}^{-3}$ of $1-\mathrm{MCP}+10 \mu \mathrm{L}^{-1}$ of ethylene; 9) $1.5 \mathrm{~g}$ $\mathrm{m}^{-3}$ of $1-\mathrm{MCP}+10 \mu \mathrm{l}^{-1}$ of ethylene.

Before and after the treatment's application and also during the postproduction phase the plants were evaluated on:

Accumulated abscission of leaves, fruits and flowers $(\%)$

The accumulated abscission of leaves, fruits and flowers (\%) was determined by the total count of leaves, fruits and flowers, respectively, before and after the treatments during the whole experiment. Only completely expanded leaves were counted. We counted the closed flower buds, in anthesis, completely opened and the fertilized ones. Fruits were separated by maturation stage in green, ripe-green and ripe.

\section{Post-production phase}

After application of the treatments, the plants were transferred to the interior of a room at $20-25^{\circ} \mathrm{C}$ and $7-10 \mu \mathrm{mol}$ $\mathrm{s}^{-1} \mathrm{~m}^{-2}$ of fluorescent light, simulating the interior of shops, supermarkets and residences. This phase was determined by the days between removing the plants from the chamber until the day they were commercially inadequate, that is, when they had 50\% leaf abscission and/or fruit and/or 50\% leaf senescence. Leaf senescence recognition was obtained by grouping the genotypes according to a common pattern of senescence.

\section{Data analysis}

The experiment was set up in a completely randomized design with 9 treatments and 3 replicates. The experimental unit consisted of one plant per pot. To analyze the data, a descriptive analysis with standard error calculation was performed. The PRISM program was used to obtain the graphs.

\section{RESULTS AND DISCUSSION}

The treatment with 1-MCP was effective in blocking the ethylene action reducing the leaves and fruits abscission of Pimentão Ornamental. There was no abscission of leaves and fruits in the plants treated with 1-MCP of the ethylene action in all evaluated concentrations; however, those treated with 1-MCP in the concentrations of 0.5 and $1.5 \mathrm{~g} \mathrm{~m}^{-3}$ maintained the $100 \%$ response of flower abscission and flower buds similar to plants treated with ethylene alone. In pre-treated 1 -MCP peppers at $1.0 \mathrm{~g} \mathrm{~m}^{-3}, 0 \%$ flower abscission and floral buds were observed even after 48 hours of exposure to ethylene (Figure 1).

This suggests that ethylene application was not sufficient for the synthesis of new binding sites nor the removal of 1-MCP of the same. 1-MCP binds to ethylene receptors with a halflife of diffusion between 7 and 12 days, which in most cases exceeds the shelf life of ornamental peppers (Serek et al., 1995). Compared with ethylene, which has a diffusion time of 2 to 10 minutes, it can be concluded that the binding of $1-\mathrm{MCP}$ to the ethylene receptor can be regarded as irreversible; however, once the 1-MCP receptor complex is metabolized, the process is reversed, and new receptors are synthesized (Sisler \& 
Serek, 1999).

Although fruit abscission was reduced in plants treated with 1-MCP, the same proportion of immature fruits abscision was found in plants treated with ethylene, with values higher than $50 \%$. On the other hand, the external control plants presented a higher proportion of abscision of mature fruits; behavior due to ordinary senescence processes.

The fruits of the plants pretreated
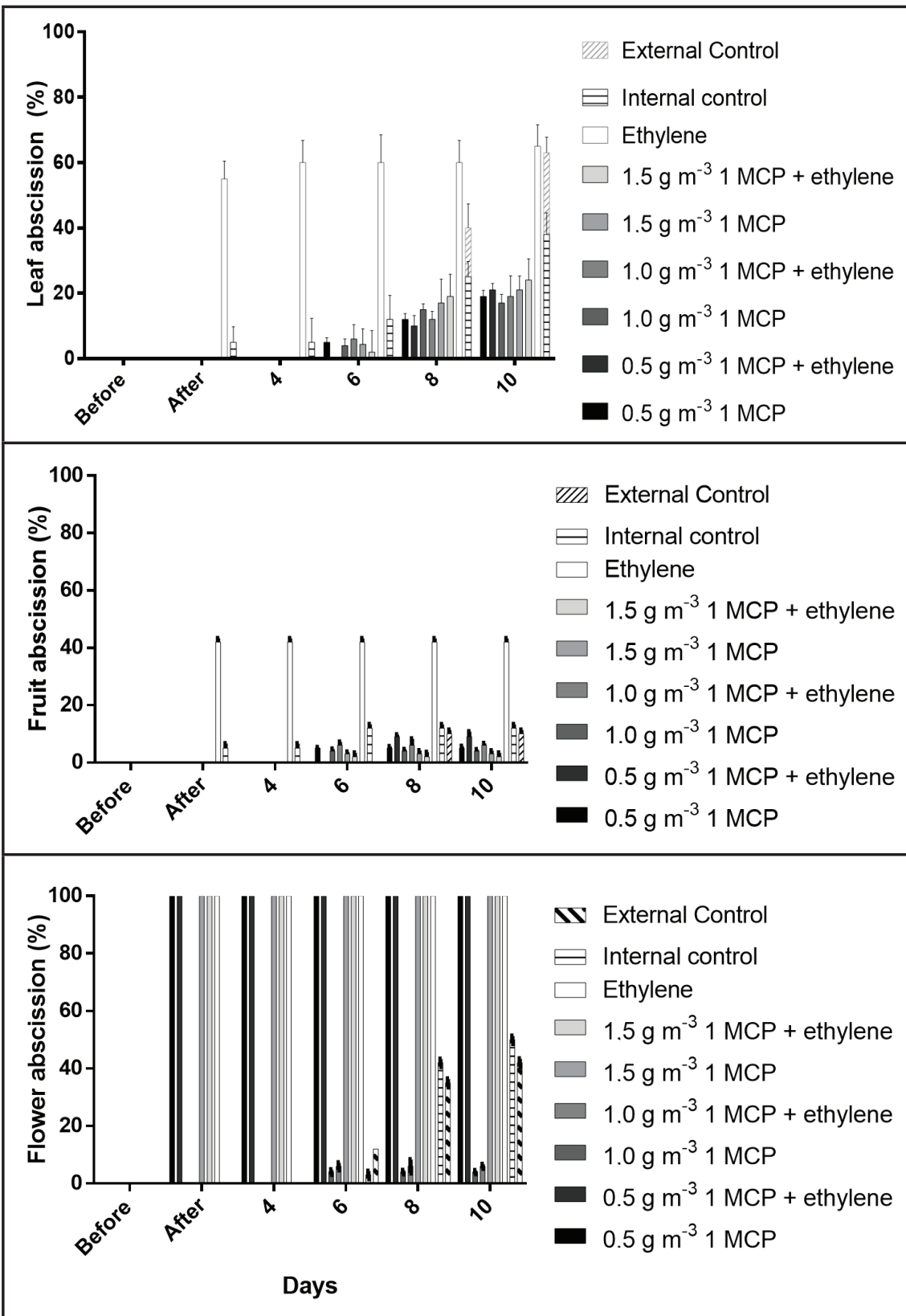

Figure 1. Accumulated abscission (\%) of leaves, fruits and flowers of 'Pimentão Ornamental' (Capsicum annuum) in vase before (day 0) and after 0.5, 1.0 and $1.5 \mathrm{~g} \mathrm{~m}-3$ and without application of $10 \mu \mathrm{L} \mathrm{L}-1$ of ethylene for 48 hours. Vertical bars indicate standard deviation of the average $(n=3)$. Viçosa, UFV, 2015.
When exposed to exogenous ethylene, the percentage of accumulated abscission of leaves was $63.70 \%$, that of flowers $100 \%$ and that of fruits was $10.41 \%$. Of the total fallen fruits, $100 \%$ were of green maturation stage. After the removal from the chamber, some leaves that persisted on the plant were yellowed (Figure 2).

It became evident that the fruits in green mature stage that persisted on the plant, had the color intensified with the application of $10 \mu \mathrm{L} \mathrm{L}^{-1}$ of ethylene. Fruit abscission was not observed in internal and external control plants.

The ornamental pepper lasted only one day after the application of ethylene for 48 hours, while plants treated with 1-MCP lasted eight days in the bench condition. Plants treated with only 1-MCP had the post-production phase increased compared to the plants of the external control, suggesting that the low radiation $\left(8-10 \mu \mathrm{mol} \mathrm{s}^{-1} \mathrm{~m}^{-2}\right.$ fluorescent light) of the room in which the plants were subjected to after treatment, induced ethylene synthesis, and that 1-MCP was effective in inhibiting the effect of this hormone produced by light stress.

Cavatte (2013), evaluating the light and temperature action on the longevity of ornamental peppers BGH 1039 and Roxa (Capsicum annuum), found that 1-MCP drastically inhibited leaf fall in both varieties when exposed to high temperature. However, the response of $1-\mathrm{MCP}$ to inhibit the ethylene effects, in the same work, depended on the variety and the luminosity conditions in which the plants were submitted.

The treatment with 1-MCP + ethylene was effective in reducing leaf abscission of Calypso cultivar, classified according to the same research as highly sensitive to exogenous ethylene. The cultivar Calypso also did not present fruit abscission when submitted to the same treatment (Segatto et al., 2013).

In orchids of the genus Cymbidium, the 1-MCP application extended the longevity of the stems regardless of the ethylene presence in the atmosphere after treatment with 1-MCP (Heyes \& Johnston, 1998).

In other flower studies, 1-MCP treatment has the greatest effect on 
inhibiting the ethylene deleterious action when applied prior to exposure to the hormone and the beneficial effect decreases if 1-MCP is applied together or after ethylene (Blankenship \& Dole, 2003). Matthiola incana stems treated with $1 \mathrm{~mL} \mathrm{~L}^{-1}$ of ethylene for 48 hours, promoted $100 \%$ petal abscission, and induced leaf epithelia. These effects were completely inhibited by pretreatment with $500 \mathrm{~nL} \mathrm{~L}^{-1}$ of $1-\mathrm{MCP}$ for 6 hours.

Celikel \& Reid (2002) found similar results on pre-treated Consolida

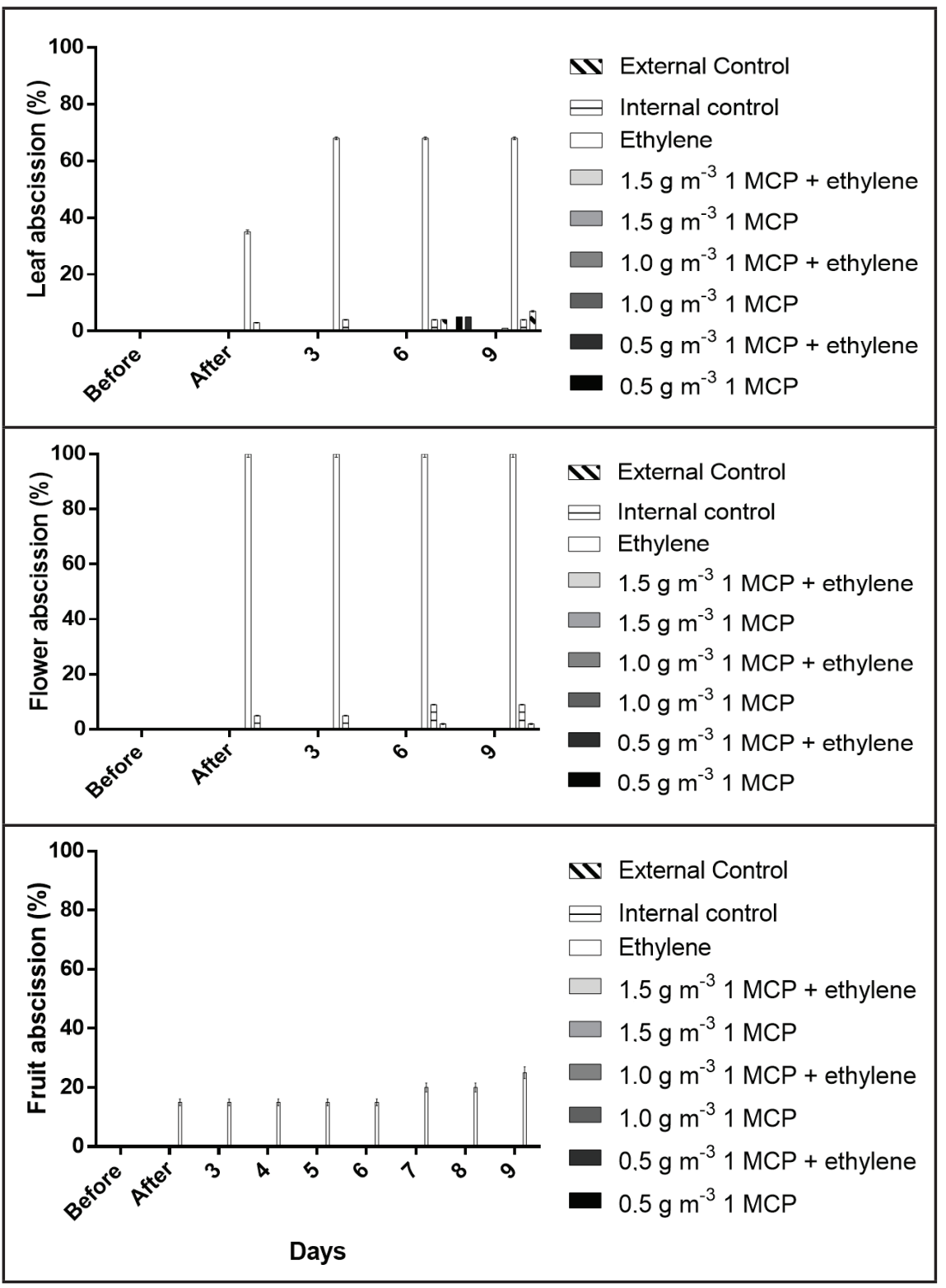

Figure 2. Accumulated abscission (\%) of leaves, flowers and fruits of Capsicum annuum before (day 0 ) and after the application of $0.5,1.0$ and $1.5 \mathrm{~g} \mathrm{~m}-3$ with and without application of $10 \mu \mathrm{L} \mathrm{L}-1$ of ethylene for 48 hours. Vertical bars indicate standard deviation of the average $(n=3)$. Viçosa, UFV, 2015. ambigua with 1-MCP. In researches performed with Dianthus caryophyllus, 1 -MCP application at $0.5 \mathrm{~nL} \mathrm{~L}^{-1}$ concentration during 24 hours was effective in blocking the deleterious effects of ethylene (Serek \& Sisler, 1997, 2001). Accelerated yellowing and early foliar leaves abscission, ethylene effect observed in brassicaceae, is reversed with the use of 1-MCP. With application of $100 \mathrm{mg} \mathrm{L}^{-1}$ of Ethrel, Consolida ambigua longevity was reduced by about $69 \%$, compared to control inflorescences. On the other hand, fumigation with $0.5 \mathrm{~g} \mathrm{~m}^{-3}$ of $1-\mathrm{MCP}$ increased longevity by $33 \%$ over the control (Santos et al., 2005).

For the studied ornamental pepper varieties, pre-treatment with $1-\mathrm{MCP}$ at $1.0 \mathrm{~g} \mathrm{~m}^{-3}$ concentration, was effective in inhibiting the ethylene action and reducing leaf, flower and fruit abscission.

\section{ACKNOWLEDGMENTS}

To Conselho Nacional de Desenvolvimento Científico e Tecnológico (CNPq), Fundação de Amparo à Pesquisa do Estado de Minas Gerais (FAPEMIG) and Comissão de Aperfeiçoamento de Pessoal do Nível Superior (CAPES).

\section{REFERENCES}

BEAUDRY, RM; KAYS, SJ. 1998. Effect of ethylene source on abscission of pepper plant organs. HortScience 23: 724-744.

BLANKENSHIP, SM; DOLE, JM. 2003. 1-Methylcyclopropene: a rewiew. Postharvest Biology and Technology 28: 1-25.

BRACKMANN, A; SESTARI, I; STEFFENS, CA; GIEHL, RFH. 2004. Qualidade da maçã cv. Gala tratada com 1-metilciclopropeno. Ciência Rural 34: 1415-1420.

BUANONG, M; MIBUS, H; SISLER, EC; SEREK, M. 2005. Efficacy of new inhibitors of ethylene perception in improvement of display quality of miniature potted roses (Rosa hybrida L.) Plant Growth Regulation 47: 29-38.

CAVATTE, RPQ; LIMA, JS; SILVA, TP; CAVETTE, PC; FINGER, FL; BARBOSA, JG. 2013. Influence of temperature and 1-Methylcyclopropene on post-production display life of ornamental pepper (Capsicum annuит L.). Acta Horticulturae 1002: 359364.

CELIKEL, FG; REID, MS. 2002. Postharvest handling of stock (Matthiola incana). HortScience 37: 144-147.

FINGER, FL; BARBOSA, JG. 2006. Postharvest physiology of cut flowers. In: NOUREDDINE, B; NORIO, S (ed). Advances in postharvest technologies for horticultural crops. Kerala: Research Signpost, 373-393.

FINGER, FL; MORAES, PJ; MAPELI, AM; BARBOSA, JG; CECON, PR. 2008. Longevity of Epidendrum ibaguense flowers as affected by pre-loading treatments and vase solution. Journal of Horticultural Science \& Biotechnology 83: 144-147.

HEYES, JA; JOHNSTON, JW. 1998. 1-Methylcyclopropene extends Cymbidium orchid vaselife and prevents damaged pollinia from accelerating senescence. New Zealand Journal of Crop and Horticultural Science 


\section{6: 319-324.}

KRAJAYKLANG, M; KLIEBER, A; DRY, PR. 2000. Colour at harvest and postharvest behaviour influence paprika and chille spice quality. Postharvest Biology and Technology 20: $269-278$

SANTOS, VR; FINGER, FL; BARBOSA, JG; BARROS, RS. 2005. Influência do etileno e do 1-MCP na senescência e longevidade das inflorescências de esporinha. Bragantia 64: 33-38.

SEGATTO, FB; FINGER, FL; BARBOSA, JG; RÊGO, ER; PINTO, CMF. 2013. Effects of Ethylene on the post-production of potted ornamental peppers (Capsicum annuum L.). Acta Horticulturae 1000: 217-222.

SEREK, M; SISLER, EC; REID MS. 1994. Novel gaseous ethylene binding inhibitor prevents ethylene effect in potted flowering plants. Journal American Society Horticulture Science 119: 1230-1233.

SEREK, M; SISLER, EC. 2001. Efficacy of inhibitors of ethylene binding in improvement of the postharvest characteristics of potted flowering plants. Postharvest Biology and Technology 23: 161-166.

SEREK, M; SISLER, EC; REID, MS. 1995. 1-methylcyclopropene, a novel gaseous inhibitor of ethylene action, improves the life of fruit, cut flowers and potted plants. Acta Horticulturae 394: 337-345.

SISLER, EC; SEREK, M. 1999. Compounds controlling the ethylene receptor. Botanical Bulletin of Academia Sinica 40. 1999.

SISLER, EC; SEREK, M. 1997. Inhibitors of ethylene responses in plants at the receptors level: recent developments. Physiologia Plantarum 100: 577-582.

SUN, Y; CHRISTENSEN, B; LIU, F; WANG, H; MÜLLER, R. 2009. Effects of ethylene and 1-MCP (1-methylcyclopropene) on bud and flower drop in mini Phalaenopsis cultivars. Plant Growth Regulation 59: 83-91. 